\title{
Chuẩn bị cho Việt Nam sẵn sàng với luật chơi mới trên thị trường quốc tế - sản xuất và kinh doanh không liên quan tới phá rừng và suy thoái rừng
}

Phạm Thu Thủy

Nguyễn Đình Thảo

Đào Thị Linh Chi

Hoàng Tuấn Long 



\title{
Chuẩn bị cho Việt Nam sẵn sàng với luật chơi mới trên thị trường quốc tế - sản xuất và kinh doanh không liên quan tới phá rừng và suy thoái rừng
}

\author{
Pham Thu Thủy \\ Trung tâm Nghiên cứu Lâm nghiệp Quốc tế (CIFOR) \\ Nguyễn Đình Thảo \\ Trung tâm Nghiên cứu Lâm nghiệp Quốc tế (CIFOR) \\ Đào Thi Linh Chi \\ Trung tâm Nghiên cứu Lâm nghiệp Quốc tế (CIFOR) \\ Hoàng Tuấn Long \\ Trung tâm Nghiên cứu Lâm nghiệp Quốc tế (CIFOR)
}


Báo cáo chuyên đề 253

C 2019 Tổ chức Nghiên cứu Lâm nghiệp Quốc tế (CIFOR)

(c) (i) Nội dung trong ấn phẩm này được cấp quyền bởi Giấy phép bản quyền Ghi nhận công của tác giả - Phi thương mại, không chỉnh sửa, thay đổi hay phát triển - Không phát sinh 4.0. http://creativecommons.org/ licenses/by-nc-nd/4.0/

DOI: $10.17528 /$ cifor/007421

Phạm TT, Nguyễn ĐT, Đào TLC và Hoàng TL. 2019. Chuẩn bị cho Việt Nam sẵn sàng với luật chơi mới trên thị trường quốc tếsản xuất và kinh doanh không liên quan tới phá rừng và suy thoái rừng. Báo cáo chuyên đề 253. Bogor, Indonesia: CIFOR.

CIFOR

Jl. CIFOR, Situ Gede

Bogor Barat 16115

Indonesia

$\mathrm{T}+62(251) 8622-622$

$F+62(251) 8622-100$

E cifor@cgiar.org

\section{cifor.org}

Chúng tôi xin cảm ơn các nhà tài trợ đã hỗ trợ cho nghiên cứu này thông qua việc đóng góp vào quỹ của CGIAR. Xin xem danh sách các nhà tài trợ: http://www.cgiar.org/about-us/our-funders/

Tất cả các quan điểm thể hiện trong ấn phẩm này là của các tác giả. Chúng không nhất thiết đại diện cho quan điểm của CIFOR, các cơ quan chủ quản của tác giả hay của các nhà tài trợ cho ấn phẩm này. 


\section{Mục lục}

Danh mục từ viết tắt $\quad$ v

Lời cảm ơn $\quad$ vi

1 Bối cảnh 1

2 Sản xuất và kinh doanh không liên quan tới phá rừng? 2

3 Tại sao Việt Nam phải quan tâm tới yêu cầu mới này của thị trường? 4

3.1 Ngành dệt may với ví dụ từ Nike 5

3.2 Ngành Cà phê và ví dụ từ Nestle 6

3.3 Ngành gỗ với ví dụ từ IKEA

3.4 Cao su với ví dụ của các công ty sản xuất lốp xe và công nghiệp xe hơi 9

3.5 Ngành Mĩ phẩm với ví dụ của L'oreal 10

4 Đề xuất các bước tiếp theo

Tài liệu tham khảo $\quad 13$ 


\section{Danh sách bảng, hình và hộp}

\section{Bảng}

1 Một số ngành nghề chính mà các công ty trên toàn cầu cam kết không sản xuất và kinh doanh liên quan đến phá rừng

2 Vai trò và các hoạt động cần thiết để hỗ trợ Việt Nam tiệm cận với việc sản xuất và kinh doanh không phá rừng.

\section{Hình}

1 Cam kết của các công ty ở mức độ chuỗi cung ứng trên thế giới và tại Việt Nam 3

2 Các ngành nghề tham gia vào cam kết trên thế giới và Việt Nam 3

3 Doanh thu bán lẻ của các doanh nghiệp cà phê năm 2017

Hộp

1 Những vấn đề cần xem xét trong chương trình nông thôn mới giai đoạn 2020 - 2035

2 Xu thế thế giới tham gia cam kết bảo vệ rừng thế nào?

3 Trường hợp ví dụ của công ty Nestle 7

4 Yêu cầu và quy trình mua, nhập gỗ từ các bên cung cấp trong đó có Việt Nam của IKEA 9 


\title{
Danh mục từ viết tắt
}

\author{
CIFOR Tổ chức Nghiên cứu Lâm nghiệp Quốc tế \\ CRP-FTA Chương trình nghiên cứu CGIAR về rừng, cây và nông lâm kết hợp \\ FDI Đầu tư trực tiếp nước ngoài \\ FLEGT Thực thi luật Lâm nghiệp, Quản trị và Thương mại Lâm sản \\ FMCG Hàng tiêu dùng nhanh (Hàng hoá đóng gói) \\ GDP Tổng sản phẩm quốc nội \\ NGO Tổ chức phi chính phủ \\ NORAD Cơ quan hợp tác phát triển $\mathrm{Na} U y$ \\ REDD+ Giảm phát thải từ mất rừng và suy thoái rừng \\ USAID Cơ quan hợp tác phát triển Mỹ \\ USD Đô la Mỹ \\ VPA Thoả thuận đối tác tự nguyện
}




\section{Lời cảm ơn}

Nghiên cứu này là một hợp phần của Nghiên cứu so sánh toàn cầu về REDD+ mà CIFOR đang tiến hành (www.cifor.org/gcs). Chúng tôi xin trân trọng cảm ơn hỗ trợ tài chính từ các nhà tài trợ bao gồm Cơ quan Hợp tác Phát triển Na Uy (NORAD) và Chương trình nghiên cứu CGIAR về rừng, cây và nông lâm kết hợp (CRP-FTA), đã hỗ trợ nghiên cứu này. 


\section{Bối cảnh}

Sản xuất và xuất khẩu các sản phâm nông lâm sản đóng góp tỉ trọng lớn trong GDP Việt Nam. Tuy nhiên, số lượng và doanh thu thu được từ các ngành hàng này phụ thuộc rất nhiều vào xu thế và yêu cầu của thị trường quốc tế. Hiện nay trên thế giới đang hình thành rất nhiều định hướng, yêu cầu mới của thị trường trong 30 năm tới đây. Nếu Việt Nam không chuẩn bị cả về chính sách, năng lực thực hiện cho các bên, Việt Nam có thể bị mất thị trường hiện có đồng thời không thể tham gia vào cuộc chơi trong thị trường mới. Hai câu hỏi chiến lược cần phải được xem xét kĩ lưỡng trong quá trình xây dựng chương trình nông thôn mới giai đoạn 2020 - 2035 bao gồm:

i. Trong 20 năm tới, luật chơi mới của thị trường quốc tế về sản phẩm nông lâm sẽ là gì để Việt Nam có thể chuẩn bị sẵn sàng tiếp nhận và tham gia cuộc chơi mới?

ii. Việt Nam sẽ cần chuẩn bị về mặt pháp lí, xây dựng năng lực cho các bên có liên quan để đón đầu thị trường mới như thế nào?

Bài viết này tổng hợp các thông tin hiện có, đồng thời dựa trên các kết quả nghiên cứu và kinh nghiệm thu được trên toàn cầu mà Tổ chức nghiên cứu lâm nghiệp quốc tế (CIFOR) đã đúc kết trong vòng 10 năm trở lại đây để thảo luận về một trong những luật chơi mới của thị trường quốc tế: Sản xuất và kinh doanh không liên quan đến phá rừng. Bài viết sẽ trả lời 3 câu hỏi chính (Hộp 1).

Hộp 1. Những vấn đề cần xem xét trong chương trình nông thôn mới giai đoạn 2020 - 2035

1. Sản xuất và kinh doanh không liên quan đến phá rừng là gì? Tại sao Việt Nam phải quan tâm tới yêu cầu mới này của thị trường?

2. Chiến lược mà các nước trên thế giới, các tập đoàn đa quốc gia đang tiến hành để chuẩn bị cho thị thị trường mới này ra sao, và điều đó sẽ ảnh hưởng tới Việt Nam thế nào?

3. Việt Nam sẽ cần phải làm gì để để đón đầu và gia nhập thị trường mới trong 30 năm tới? 


\section{Sản xuất và kinh doanh không liên quan tới phá rừng?}

Biến đổi khí hậu và giảm khí phát thải đang là vấn đề quan tâm nóng bỏng trên toàn cầu. Các hoạt động liên quan đến phá rừng và suy thoái rừng gây ra $20 \%$ trong tổng lượng phát thải toàn cầu. Tuy nhiên, $70 \%$ diện tích rừng bị phá trên toàn cầu là do mở rộng diện tích sản xuất nông nghiệp và chuyển đổi rừng sang mục đích nông nghiệp. Trước áp lực và tác động tiêu cực của biến đổi khí hậu, xã hội và người tiêu dùng đang đòi hỏi và yêu cầu các doanh nghiệp cung cấp các sản phẩm thân thiện với môi trường. Một trong những yêu cầu đó là Sản xuất và kinh doanh không liên quan tới phá rừng. Trong thực tế, $87 \%$ người tiêu dùng tại Châu Âu yêu cầu tất cả các sản phẩm trên thị trường phải được kiểm tra và thẩm định không được liên quan đến phá rừng hoặc làm tổn hại tới rừng (The sustainable trade initiative 2019). Tuy chưa có con số thông báo chính thức, nhưng tại nhiều diễn đàn thúc đẩy phát triển đầu tư tại Mỹ và Châu Á Thái Bình Dương cũng đưa ra những con số dự báo tương tự. Chính điều này đã thúc đẩy các quốc gia có nền kinh tế dựa vào ngành nông nghiệp và các tập đoàn lớn có sử dụng các sản phẩm nông lâm sản phải xem xét, đầu tư và chuẩn bị cho luật chơi mới thông qua xây dựng các yêu cầu xuất nhập khẩu, yêu cầu kiểm toán, quy trình đấu thầu, quy trình mua bán hàng hóa, thí điểm hệ thống giám sát và đánh giá và nâng cao năng lực cho các bên có liên quan để kiểm soát nguồn gốc hàng hóa, đảm bảo không liên quan đến phá rừng và suy thoái rừng. Ví dụ như chính phủ Na Uy đã xây dựng quy trình và chính sách yêu cầu các sản phẩm liên quan đến đậu nành làm thức ăn cho vật nuôi phải chứng minh được nguồn gốc, đảm bảo không có liên quan đến phá rừng và suy thoái rừng. Chính phủ Anh cũng xây dựng các chính sách và quy trình kiểm soát các sản phẩm nhập khẩu từ gia súc gia cầm, dầu cọ sử dụng trong ngành mĩ phẩm, thuốc, đồ ăn, gỗ cũng phải đảm bảo không bắt nguồn từ hoạt động phá rừng.

Hộp 2 cho thấy có rất nhiều quốc gia, các sáng kiến thị trường, cam kết chính trị liên quan đến sản xuất và kinh doanh không phá rừng với sự tham gia của hàng nghìn tập đoàn đa quốc gia trên thế giới. Các công ty tập đoàn này có doanh thu hàng năm ít nhất là 7.3 nghìn tỉ USD hàng năm và có mặt trên toàn cầu (Forest Trends 2016 và South Pole n.d)

Hộp 2. Xu thế thế giới tham gia cam kết bảo vệ rừng thế nào?

- 240 các cơ quan, doanh nghiệp tài chính trên toàn cầu (ví dụ: Ngân hàng, các quỹ ủy thác, các tổ chức quản lí tài chính), sở hữu tài sản trên 15 nghìn tỉ USD đã kí vào Hiệp ước "Công bố rừng" năm 2014.

- 34 công ty toàn cầu đã kí vào UN Declaration on Forests (Cam kết liên hợp quốc về bảo vệ rừng)

- 416 thành viên của Consumer Goods Forum bao gồm WalMart và Nestlé đã cam kết chuối sản xuất và cung ứng của họ không còn liên quan gì đến phá rừng năm 2020 and 2030. Diễn đàn người tiêu dùng tốt (The Consumer Good Forum) là một sáng kiến toàn cầu với sự tham gia của rất nhiều ngành kinh tế, thương mại, ngân hàng, các bên cung cấp dịch vụ trên 70 quốc gia lập nên. Tổng thu nhập và lãi ròng của các công ty tham gia diễn đàn này lên tới 2.5 nghìn tỉ Euro và họ tạo công ăn việc làm trực tiếp cho 10 triệu người và hơn 90 triệu người nữa trong chuỗi sản xuất nông nghiệp của họ trên toàn câu.

- Hiện nay trên toàn cầu có 579 công ty cam kết chuỗi cung ứng sản xuất của họ không liên quan đến phá rừng và suy thoái rừng trên toàn cầu.

Nguồn: Forest Trends 2016 và South Pole n.d 
Hình 1 cũng cho thấy không chỉ các doanh nghiệp trực tiếp sản xuất sản phẩm, mà các doanh nghiệp tham gia sản xuất, chế biến, thu mua, trung gian, bán lẻ, bán buôn, kinh doanh đều tham gia tích cực vào cam kết không phá rừng.

Trên 70\% điện tích rừng bị phá là do sản xuất nông nghiệp. 49\% trong tổng số này là do sản xuất nông nghiệp trái phép và $24 \%$ sản phẩm từ các hoạt động trái phép này được xuất khẩu ra thị trường quốc tế (South Pole n.d). Mặc dù các công ty cam kết kinh doanh và sản xuất liên quan đến phá rừng hoạt động trên nhiều ngành nghề (Hình 2), số lượng và cam kết tập trung vào ngành nông nghiệp và thực phẩm với các mặt hàng phổ biến như: cà phê, cao su, dầu cọ, sản phẩm gỗ, đậu nành, thịt gia súc gia cầm (Wensing 2019).

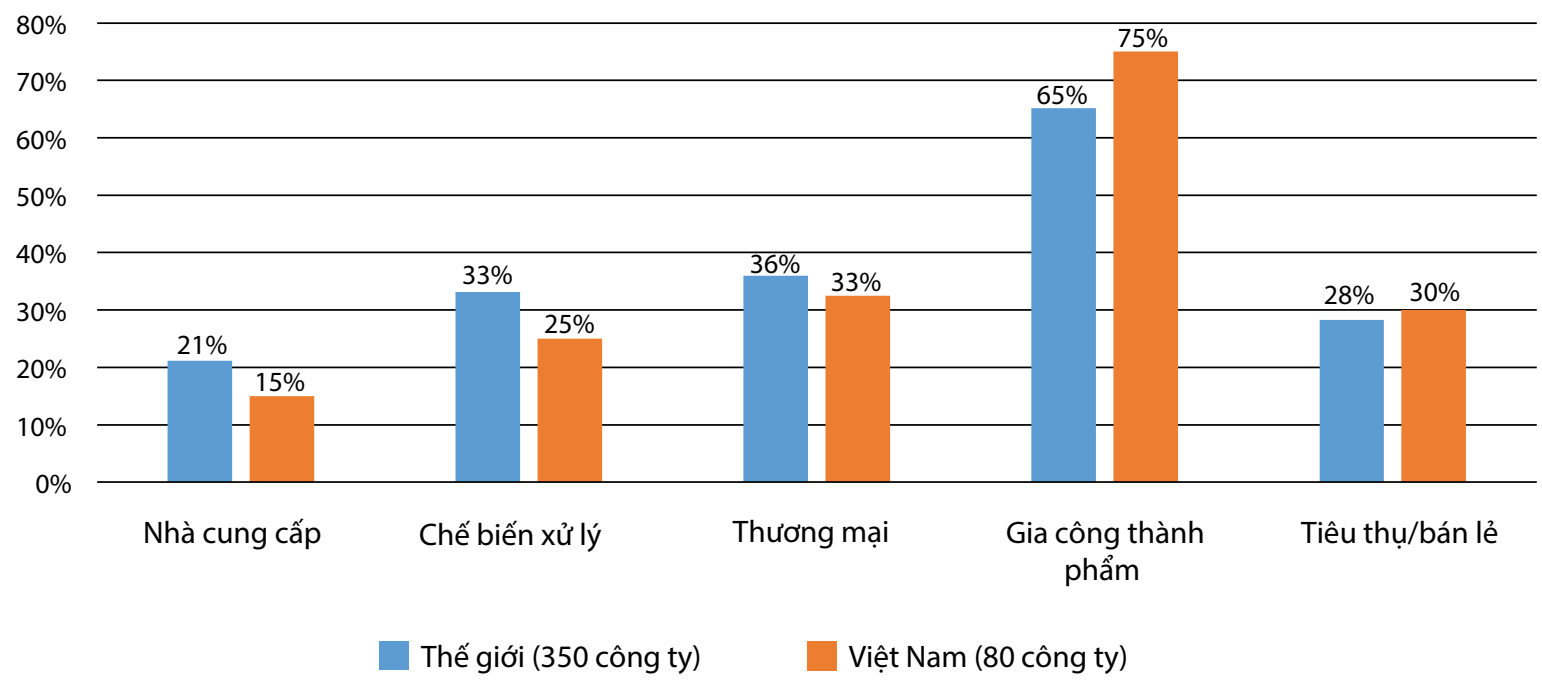

Hình 1. Cam kết của các công ty ở mức độ chuỗi cung ứng trên thế giới và tại Việt Nam Nguồn: Tổng hợp từ cơ sở dữ liệu của forest500.org

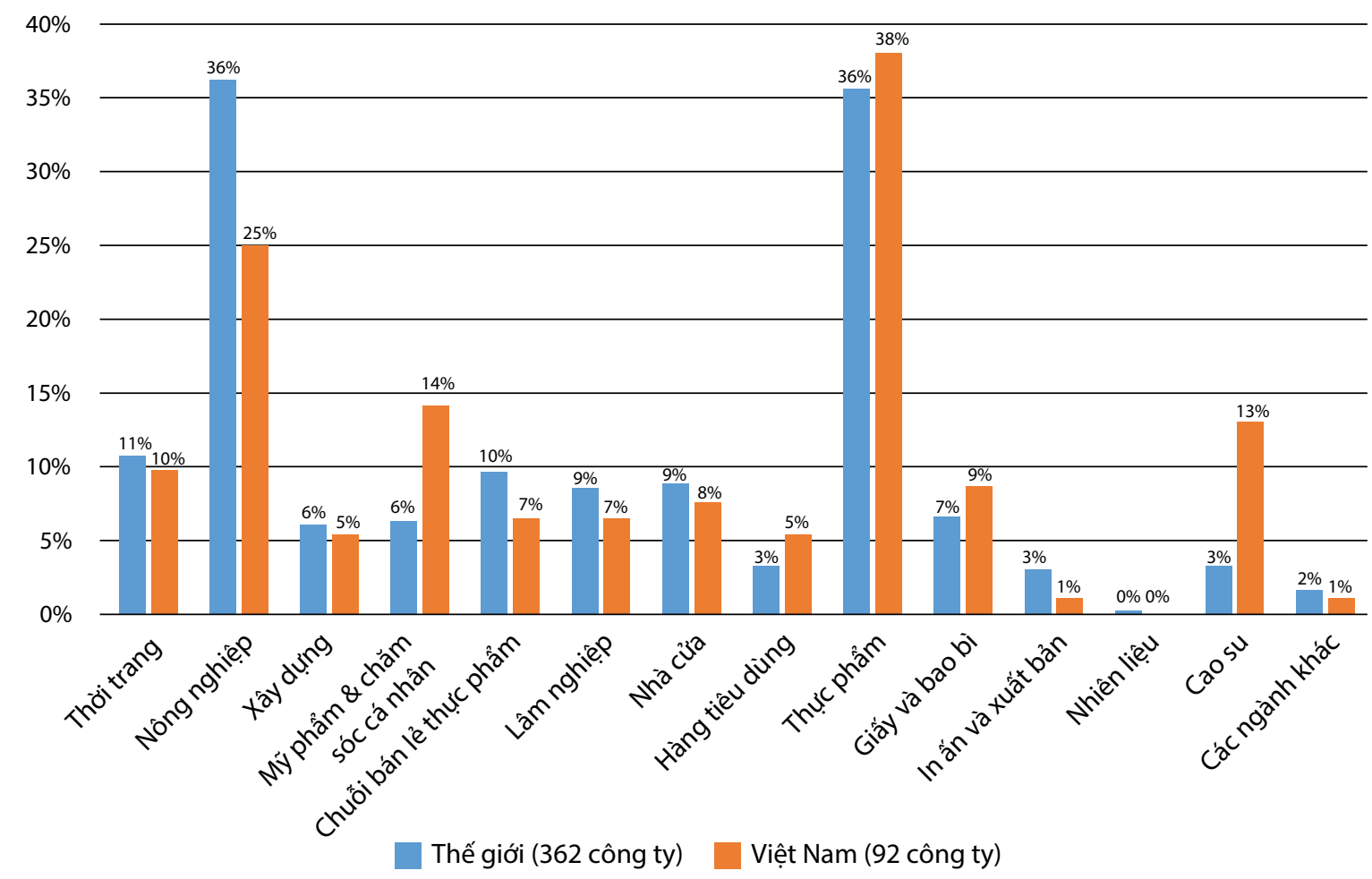

Hình 2. Các ngành nghề tham gia vào cam kết trên thế giới và Việt Nam

Nguồn: tổng hợp từ dữ liệu của forest500.org và WWF 


\section{Tại sao Việt Nam phải quan tâm tới yêu cầu mới này của thị trường?}

Theo nghiên cứu của Trung tâm nghiên cứu lâm nghiệp quốc tế (CIFOR), tại Việt Nam có 92 công ty hoạt động trong 21 ngành nghề đang tham gia cam kết kinh doanh và sản xuất không phá rừng đến năm 2020 (Bảng 1 và Hình 2).

Tuy chỉ chiếm $22.7 \%$ số lượng cam kết trên toàn cầu, các công ty này lại sở hữu và thâu tóm thị phần lớn tại Việt Nam và đóng góp kinh tế chủ lực cho nền kinh tế nước nhà. Phần dưới đây sẽ trình bày một vài ví dụ công ty và ngành nghề liên quan để thấy rõ tác động kinh tế rõ rệt nếu chuỗi sản xuất và kinh doanh ngành nghề này tại Việt Nam không kịp thời chuẩn bị đón đầu và gia nhập thị trường mới.

Bảng 1. Một số ngành nghề chính mà các công ty trên toàn cầu cam kết không sản xuất và kinh doanh liên quan đến phá rừng

\begin{tabular}{|c|c|c|}
\hline & Số lượng công ty & Tên công ty \\
\hline \multicolumn{3}{|l|}{ Thời trang } \\
\hline - Trang phục \& giày dép & 9 & $\begin{array}{l}\text { H \& M Hennes \& Mauritz AB; Tapestry; Marks \& Spencer } \\
\text { Group PLC; Inditex S.A.; Fast Retailing, Asics Corp.; Nike Inc.; } \\
\text { Pou chen; Associated British Foods Plc }\end{array}$ \\
\hline - Phụ kiện \& hành lý & 4 & $\begin{array}{l}\text { H \& M Hennes \& Mauritz AB; Tapestry; Marks \& Spencer } \\
\text { Group PLC; Inditex S.A. }\end{array}$ \\
\hline \multicolumn{3}{|l|}{ Nông nghiệp } \\
\hline - Nông nghiệp & 5 & $\begin{array}{l}\text { Archer Daniels Midland Co.; Musim Mas; Sime Darby Bhd.; } \\
\text { Wilmar International Ltd.; Bunge Ltd. }\end{array}$ \\
\hline - Sản phẩm nông nghiệp & 14 & $\begin{array}{l}\text { Louis Dreyfus; Ameropa Ltd.; Sadesa; Glencore; Archer } \\
\text { Daniels Midland Co.; Musim Mas; Sime Darby Bhd.; Wilmar } \\
\text { International Ltd.; Bunge Ltd.; Charoen Pokphand Group; } \\
\text { Cargill; Mitsubishi Corp.; COFCO; Olam International }\end{array}$ \\
\hline - Thức ăn chăn nuôi & 11 & $\begin{array}{l}\text { Charoen Pokphand Group; Cargill; Haid Group; CJ } \\
\text { Cheiljedang Corporation; De Heus; Danish Agro; InVivo; } \\
\text { New Hope Group; East Hope Group; Japfa Ltd; Uni- } \\
\text { President Enterprises Corp. }\end{array}$ \\
\hline Xây dựng & 5 & $\begin{array}{l}\text { Mitsubishi Corp;; Daiwa House Group; Sumitomo Forestry; } \\
\text { Danzer Group; Nippon Paper Industries Co. Ltd. }\end{array}$ \\
\hline $\begin{array}{l}\text { Mỹ phẩm \& chăm sóc cá } \\
\text { nhân }\end{array}$ & 13 & $\begin{array}{l}\text { Esteé Lauder Companies Inc.; GlaxoSmithKline Plc; } \\
\text { Shiseido Co. Ltd.; AmorePacific Corp; CK Hutchison } \\
\text { Holdings; Kao Corp.; Henkel AG \& Co. KGaA; Procter \& } \\
\text { Gamble Co.; Colgate-Palmolive Co.; Unilever PLC; Kimberly- } \\
\text { Clark Group; Unicharm Corporation }\end{array}$ \\
\hline Chuỗi bán lẻ thực phẩm & 6 & $\begin{array}{l}\text { Marks \& Spencer Group PLC; Charoen Pokphand Group; CK } \\
\text { Hutchison Holdings; AEON Co. Ltd.; Association Familiale } \\
\text { Mulliez (AFM); Lotte Co. Ltd. }\end{array}$ \\
\hline Lâm nghiệp & 6 & $\begin{array}{l}\text { COFCO; Olam International; Sumitomo Forestry; Danzer } \\
\text { Group; Oji Holdings Corp.; International Paper }\end{array}$ \\
\hline
\end{tabular}


Bảng 1. Tiếp trang trước

\begin{tabular}{|c|c|c|}
\hline & Số lượng công ty & Tên công ty \\
\hline \multicolumn{3}{|l|}{ Nhà cửa } \\
\hline • Nội thất \& sàn nhà & 7 & $\begin{array}{l}\text { Inditex S.A.; Association Familiale Mulliez (AFM); Adient; } \\
\text { Lear Corp.; Nitori Holdings Co. Ltd.; Ashley Furniture } \\
\text { Industries Inc.; 3M Company }\end{array}$ \\
\hline $\begin{array}{l}\text { - Vật dụng sửa chũa nhà } \\
\text { cửa }\end{array}$ & 1 & Association Familiale Mulliez (AFM) \\
\hline Hàng tiêu dùng & 5 & $\begin{array}{l}\text { Kao Corp.; Henkel AG \& Co. KGaA; Procter \& Gamble Co.; } \\
\text { Colgate-Palmolive Co.; Unilever PLC }\end{array}$ \\
\hline \multicolumn{3}{|l|}{ Thực phẩm } \\
\hline - Thực phẩm đóng gói & 14 & $\begin{array}{l}\text { Mitsubishi Corp.; COFCO; Olam International; Uni-President } \\
\text { Enterprises Corp.; Associated British Foods Plc; Unilever } \\
\text { PLC; Koninklijke FrieslandCampina N.V.; Lotte Co. Ltd.; } \\
\text { Nestlé S.A.; Mars Inc.; Mondelez International Inc.; Kewpie } \\
\text { Corp.; Yakult Honsha Co. Ltd.; Yamazaki Baking Co. }\end{array}$ \\
\hline - Gia vị & 6 & $\begin{array}{l}\text { Archer Daniels Midland Co; Cargill; Associated British } \\
\text { Foods PIc; Koninklijke DSM N.V.; BASF SE; DuPont }\end{array}$ \\
\hline - Dầu mõ & 5 & $\begin{array}{l}\text { Musim Mas; Sime Darby Bhd.; Wilmar International Ltd.; } \\
\text { Bunge Ltd.; Uni-President Enterprises Corp. }\end{array}$ \\
\hline - Bơ sũa & 1 & Koninklijke FrieslandCampina N.V. \\
\hline - Đồ ăn nhanh & 7 & $\begin{array}{l}\text { McDonald's Corp.; Restaurant Brands International; } \\
\text { Doctor's Associates Inc.; Dunkin' Brands Group Inc.; Yum! } \\
\text { Brands Inc.; Starbucks Corp.; Domino's Pizza Inc. }\end{array}$ \\
\hline Giấy và bao bì & 8 & $\begin{array}{l}\text { Nippon Paper Industries Co. Ltd.; Kimberly-Clark Group; } \\
\text { Unicharm Corporation; Oji Holdings Corp.; 3M Company; } \\
\text { Nine Dragons Paper Holdings; Gold Best Holdings; } \\
\text { International Paper }\end{array}$ \\
\hline In ấn và xuất bản & 1 & Dai Nippon Printing \\
\hline Khác & 3 & BASF SE; DuPont; Royal Dutch Shell \\
\hline \multicolumn{3}{|l|}{ Công nghiệp ô tô } \\
\hline Cao su & 10 & $\begin{array}{l}\text { Michelin, Pirelli, Bridgestone, Goodyear, Sumitomo, } \\
\text { Continental, Yokohama, Hankook Toyo Tires, Halcyon }\end{array}$ \\
\hline Sản xuất ô tô & 3 & General Motors, BMW, Toyota \\
\hline Tổng số & $92^{\mathrm{a}}$ & \\
\hline
\end{tabular}

a Số liệu có phần khách so với Hình 2 vì chúng tôi đã bổ sung cập nhật các số liệu cho tới năm 2019 trong khi số liệu của Hình 2 mới chỉ cập nhật tới năm 2018.

Nguồn: Forest500 2018 và WWF 2018, CIFOR own data 2019.

\subsection{Ngành dệt may với ví dụ từ Nike}

Ngành dệt may là một trong những ngành mũi nhọn của Việt Nam, ngành có kim ngạch xuất khẩu lớn thứ hai với giá trị xuất khẩu đóng góp từ 10-15\% vào GDP. Trong những năm gần đây, ngành dệt may Việt Nam liên tục phát triển với tốc độ bình quân 17\% một năm. Việt Nam là một trong 10 nước xuất khẩu dệt may lớn nhất thế giới. Các doanh nghiệp FDI tuy chỉ chiếm $25 \%$ về số lượng nhưng đóng góp đến hơn 60.64\% vào kim ngạch xuất khẩu may mặc trong năm 2017 của ngành dệt may Việt Nam (VIRAC 2019). Năm 2018 là một năm thành công đối với hoạt động xuất khẩu của ngành dệt may Việt Nam với tổng kim ngạch xuất khẩu đạt trên 36 tỷ USD, tăng 16,01\% so với năm 2017 (Lê 2018). Ngành dệt may cũng là ngành có nhiều công ty tham gia cam kết sản xuất và kinh doanh không liên quan đến phá rừng trên toàn cầu. 
Tại Việt Nam, Nike là một trong những nhà đâu tư sở hữu thị phần lớn nhất trên thế giới và trong nước. Nike sở hữu thị phần lớn nhất về ngành may mặc trên toàn cầu (38\%). Doanh thu bán hàng hàng năm của Nike lên đến 23 tỉ đô la Mỹ (The Forbes n.d). Nike cam kết sẽ giảm lượng phát thải $50 \%$ trên toàn cầu cho tới năm 2025, và phần lớn liên quan đến phá rừng. Nike hiện nay có 105 công ty đang cung ứng các mặt hàng cho Nike với 440,922 công nhân đang làm việc tại Việt Nam (Nike n.d). Nike có 150 nhà máy sản xuất các sản phẩm may mặc ở 14 quốc gia trên toàn cầu và 105 công ty tại Việt Nam sản xuất và chiếm tới 43\% tổng sản lượng sản lượng sản xuất may mặc (CSIMarket n.d). 41\% người lao động trên toàn cầu sản xuất các khâu đoạn cuối cùng của sản phẩm Nike là người Việt Nam. Các nhà máy của Nike tại Việt Nam đóng góp 16\% trên toàn lượng sản xuất của Nike trên thế giới (Joshua n.d).

Nike và những bên cung ứng sản phẩm cho Nike tại Việt Nam đã tạo ra việc làm và là nguồn thu thuế của Việt Nam. Tuy nhiên, vấn đề môi trường mà đặc biệt là sản xuất và kinh doanh hàng hóa không liên quan đến phá rừng đã được Nike cam kết loại bỏ từ năm 2009. Nike đã ra chính sách thu mua hàng mới đối với Brazil để tránh các sản phẩm da giầy của mình liên quan đến phá rừng (Nike News 2009, Mat Mc 2009 và Mongabay 2009). Tại Việt Nam, Nike cũng đang làm việc với các bên cung ứng của mình để tìm giải pháp giảm phát thải (Aparna 2016). Ngoài Nike, các công ty thời trang khác như $\mathrm{H} \& M$, Addidas cũng gia nhập cam kết không phá rừng và đang nỗ lực xây dựng chính sách mua hàng của mình để đảm bảo chỉ lựa chọn các bên cung ứng kinh doanh bền vững và không phá rừng (Walker và cộng sự 2013 và Siegle 2013). Những xu thế ở kỉ nguyên bảo vệ rừng và ưu tiên những nguồn năng lượng sạch tái tạo này, nếu Việt Nam không bắt kịp, sẽ rất dễ đánh mất một thị trường lớn, gây ra thiếu hụt nguồn thu nhập đáng kể đánh vào nền kinh tế quốc dân.

\subsection{Ngành Cà phê và ví dụ từ Nestle}

Cà phê là một trong những ngành kinh tế chủ lực của Việt Nam. Theo tính toán từ số liệu thống kê sơ bộ của Tổng cục Hải quan, trong 8 tháng đầu năm 2017 cả nước xuất khẩu trên 1,02 triệu tấn cà phê, thu về trên 2,29 tỷ USD (caphenguyenchat, n.d). Theo thông tin từ Hiệp hội Cà phê - Ca cao Việt Nam (VICOFA), hiện Việt Nam có khoảng 150 doanh nghiệp xuất khẩu cà phê và hơn 3000 đại lí thu mua cà phê trên cả nước. Cũng theo VICOFA, tuy số lượng doanh nghiệp nước ngoài đầu tư vào ngành cà phê không lớn, họ lại chiếm tỉ trọng lớn trong tổng kim ngạch xuất khẩu cà phê nhân tại Việt Nam. Doanh thu thuần của các doanh nghiệp cà phê trong năm 2017 đạt mức tăng trưởng trung bình khoảng 12-13\% so với năm 2016, cao hơn hẳn so với các ngành khác (Cổng thông tin quốc gia về đăng kí doanh nghiệp 2018). Các công ty như Nestlé có doanh thu ròng trên 100 tỉ đô la Mỹ và Walmart có doanh thu trên 470 tỉ đô la Mỹ.

Tuy ngành cà phê là ngành trọng điểm của Việt Nam, nhiều báo cáo trên thế giới và trong nước đã chỉ rõ cà phê là một trong những nguyên nhân chính dẫn đến phá rừng và suy thoái rừng tại Việt Nam cũng như trên toàn cầu. Tập đoàn Nestle, đơn vị thu mua cà phê lớn nhất của Việt Nam và cũng là bên công ty có doanh thu bán lẻ lớn nhất Việt Nam (Hình 3), cũng là một trong

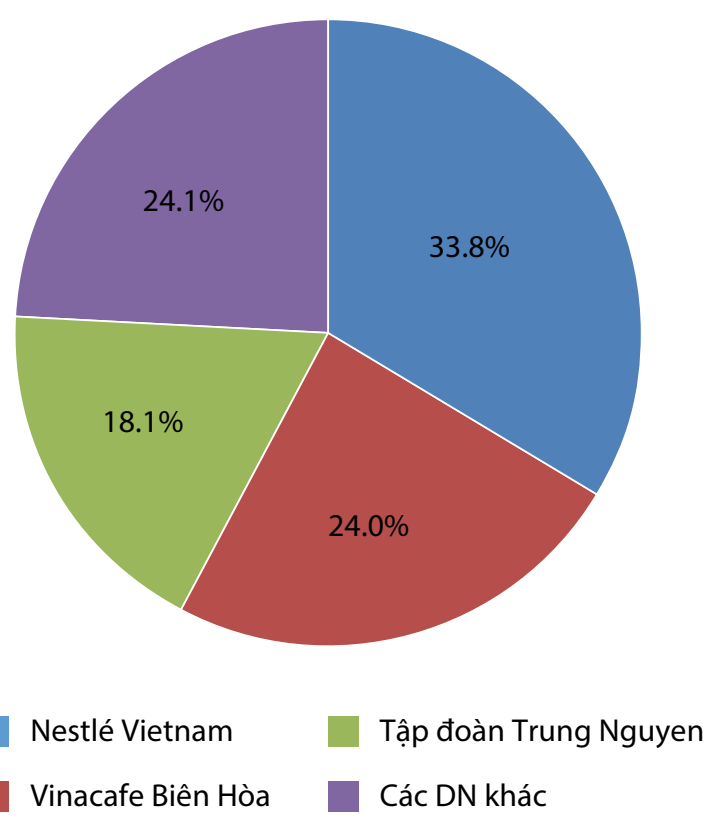

Hình 3. Doanh thu bán lẻ của các doanh nghiệp cà phê năm 2017 
những công ty đầu tiên trên thế giới cam kết vào việc sản xuất kinh doanh không liên quan đến phá rừng (Hộp 3).

Trong vòng 20 năm qua, đầu tư của Nestle vào thị trường Việt Nam đã tăng từ 24 triệu USD năm 1995 lên đến 520 triệu USD vào năm 2015. Nestle Việt Nam đã có doanh thu gần như tăng gấp đôi trong 4 năm trở lại đây và trở thành một trong những tập đoàn về sản xuất thức ăn, đồ uống FMCG lớn nhất tại Việt Nam (Hình 3).

Việc Nestle là khách hàng lớn nhất thu mua cà phê tại Việt Nam và với định hướng thị trường không liên quan đến phá rừng của Nestle tới năm 2020 đặt ra những yêu cầu mới cho các hộ và doanh nghiệp đang trồng, khai thác và kinh doanh cà phê phải tuân theo bởi nếu không đáp ứng được yêu cầu này vào năm 2020, tác động về kinh tế có thể rất đáng kể. Cụ thể:

- Việt Nam là thị trường phát triển nhanh nhất của Nestle tại Châu Á và công ty đã đóng góp to lớn vào FDI của Việt Nam trong vòng 30 năm qua --- > không đáp ứng yêu cầu chuỗi hàng hóa của Nestle, Việt Nam có thể đánh mất doanh nghiệp này do Nestle có thể chuyển sang thị trường khác đã xây dựng và vận hành quy trình chuẩn tránh phá rừng sẵn có và đáp ứng yêu cầu.

- Hàng năm, Nestle thu mua tối thiểu 20-25\% tổng sản lượng cà phê sản xuất tại Việt Nam. Nestle cũng đầu tư khoảng 600 triệu USD cho chuỗi cung ứng và xuất khẩu cà phê tại Việt Nam. Ngoài ra Nestle còn là công ty có doanh thu cao nhất năm 2017 chỉ sau có Vinamilk $\rightarrow$ Nếu Nestle đưa ra yêu cầu mới và quy trình mới phải tuân thủ liên quan đến không phá rừng mà các hộ gia đình và doanh nghiệp không chuẩn bị sẵn sàng và thực hiên được, sản lượng cà phê và sữa sản xuất ra có thể trở nền tồn đọng, không bán được và có thể giá bán trên cả nước sẽ bị hạ thấp xuống.

- Nestle được Bộ Tài Chính công nhận là tập đoàn đa quốc gia đóng góp thuế nhiều thứ 59 tại Việt Nam. Tổng đầu tư của Nestle tại Việt Nam cũng đạt con số cao lên đến 108.7 triệu USD tại Hưng Yên và đóng góp mạnh mẽ vào phát triển kinh tế của tỉnh --- > Nếu Nestle rút và không thể thu mua và sản xuất các mặt hàng cà phê do các doanh nghiệp không đáp ứng được yêu cầu chứng minh không phá rừng, tiềm năng đóng góp kinh tế này có thể bị mất.

- Nestle có 6 nhà máy tại Việt Nam với mục tiêu tạo ra việc làm cho hàng nghìn người lao động Việt Nam (Lan 2019). Với việc mở rộng chuỗi dây chuyền sản xuất NESCAFÉ Dolce Gusto tại Đồng Nai vào tháng 7 năm 2019, Nestle đang muốn mở rộng sản xuất các mặt hàng này từ 2,500 tấn cà phê của Việt Nam với dự định tăng nhanh con số này trong thời gian tới (VietnamPlus 2019).

- Nestle cũng đang sở hữu trên $1 / 3$ chuỗi thị trường bán lẻ trên Việt Nam và có doanh thu lớn thứ 2 trên thị trường liên quan đến các mặt hàng sữa (chỉ sau có Vinamilk) (Dũng 2019) đông thời cung cấp việc làm cho hơn 3000 người lao động tại Việt Nam (An 2016). Nếu không đủ sức cạnh tranh trên thị trường, hàng nghìn người lao động tại Việt Nam có nguy cơ bị mất việc.

\section{Hộp 3. Trường hợp ví dụ của công ty Nestle}

Tại các nước khác, Nestle chỉ mạnh về 1-2 mặt hàng và thương hiệu, nhưng ở Việt Nam, Nestle có mặt trên các thị trường với đầy đủ các mặt hàng và thương hiệu bao gồm Milo (là thương hiệu nổi tiếng và thành công, có doanh thu lớn nhất), NESCAFÉ, MAGGl, Nestlé, La Vie và sữa trẻ em NAN.

Năm 2010, Nestle chính thức công bố sẽ chấm dứt hiện tượng phá rừng trong chuỗi cung ứng và sản xuất của họ vào năm 2020. Nestle đã xây dựng bản đồ xác định các rủi ro trên toàn bộ chuối cung ứng trên toàn cầu và xác định được Nestle hiện đang và sẽ mua các loại sản phẩm có nguồn gốc từ:

- Đất nông nghiệp xen kẽ với rừng và đất rừng

- Đất chuyển đổi từ đất rừng sang đất nông nghiệp

- Đất chặt phá từ rừng trực tiếp

Nestle Waters còn sở hữu và cho thuê rừng để các công ty nước khoáng Nestle sử dụng. Khi cấp chứng 
Hộp 3. Tiếp trang trước

chỉ và quyết định mua hàng, Nestle sẽ đánh giá và kiểm duyệt trên các tiêu chí sau:

- Thực hiện đầy đủ với các quy định của luật pháp trong và ngoài nước

- Thực hiện thống nhất và toàn diện trên toàn thế giới

- Có quy trình quản lí và ra quyết định có sự tham gia của các bên có liên quan

- Có được sự ủng hộ của NGO

- Tôn trọng và thực thi các quyền dành cho người dân tộc thiểu số

- Gắn kết và hỗ trợ các hộ gia đình quy mô nhỏ

- Khả năng tránh và loại bỏ các hoạt động có tác động xấu tới rừng và bảo tồn, kiểm tra chuỗi giá trị hàng hóa

- Sử dụng hạn mức và thời gian cho phép do Forest Stewardship Council (FSC), the Roundtable on Sustainable Palm Oil (RSPO) and Roundtable on Responsible Soy (RTRS) thông qua khi quyết định chuyển đổi đất rừng và khai thác rừng.

Nestle sẽ không mua hàng từ bất cứ ai có liên quan đến phá rừng và chuyển đổi đất rừng. Nestle có một bộ phận độc lập để cấp chứng chỉ do Nestle quy định và vận hành để chứng thực các công ty có đạt chuẩn mực này không. Nesle cam kết rằng sản phẩm liên quan đến cà phê, giấy và bìa, gỗ, dầu cọ, các sản phẩm về sữa, đậu tương,các sản phẩm nông nghiệp, thịt, sữa, cacao mà họ mua và sử dụng sẽ: Không dẫn đến phá rừng và không dẫn đến suy giảm đa dạng sinh học. Các bên cung ứng buộc phải chứng minh họ có khả năng theo dôi, sử dụng phương pháp và hệ thống chuỗi giá trị để khẳng định thời gian sẽ thực hiện được cam kết này và được bên thứ 3 kiểm tra và cấp chứng chỉ. Khi các công ty không đạt được các tiêu chuẩn này, Nestle sẽ không mua hàng của các doanh nghiệp này nữa. Nestle theo dõi chuỗi cung ứng sản phẩm liên quan đến dầu cọ bằng công nghệ ảnh vệ tinh và sẽ tiến hành ứng dụng khoa học công nghệ để giám sát và quản lí chuỗi cung ứng liên quan đến ngành cà phê, giấy và đậu nành. Với các nhà cung ứng, Nestle cho phép chuẩn bị trong vòng 3 năm và sau 5 năm phải tuyệt đối tuân thủ luật và yêu cầu liên quan đến phòng tránh phá rừng.

Nguồn: Nestle 2019

Ngoài Nestle, các công ty cà phê quốc tế khác bao gồm Jacobs Douwe Egberts, Louis Dreyfus and ACOM, The Sustainable Trade Initiative và các công ty Hà Lan và Việt Nam cũng kí kết sẽ bảo vệ rừng tự nhiên với mục tiêu đến năm 2025, phá rừng liên quan tới việc trồng và sản xuất cà phề sẽ phải được chấm dứt (The sustainable trade initiative 2019).

\subsection{Ngành gỗ với ví dụ từ IKEA}

Năm 2018 đánh dấu sự thành công vượt trội của ngành gỗ Việt Nam với tốc độ tăng trưởng xuất khẩu gỗ và các sản phẩm đồ gỗ tăng rất mạnh đạt hơn 9 tỷ đô la, đứng thứ 5 thế giới và thứ 2 tại châu Á, chiếm khoảng 6-7\% thị phần thế giới (Diễn Đàn Doanh Nghiệp 2019). Theo báo cáo của Tổng cục Lâm nghiệp, xuất khẩu gỗ và lâm sản đạt hơn 6 tỉ USD trong 8 tháng đầu năm 2019, tăng 17,5\% so với cùng kỳ năm 2018 (Gỗ Việt 2019). Việt Nam đã tham gia VPA/FLEGT cũng như có Chương trình hành động REDD+ quốc gia (Giảm phá rừng và suy thoái rừng). Tuy nhiên, ngoài cam kết và luật chơi của thị trường liên quan đến truy xuất nguồn gốc gỗ bền vững, yêu cầu mới của thị trường liên đến cam kết kinh doanh và sản xuất không phá rừng cũng tác động không nhỏ tới các doanh nghiệp trong tương lai. Theo nhiều nghiên cứu, Việt Nam hiện có trên 3000 cơ sở và doanh nghiệp chế biến gỗ, trong đó chủ yếu là quy mô vừa và nhỏ với hơn 300,000 lao động (Tô và Canby 2011). Hỗ trợ các doanh nghiệp vừa và nhỏ này đáp ứng yêu cầu mới của các công ty và người mua lớn, như ví dụ IKEA dưới đây đang đặt ra các thách thức mới cho quốc gia.

IKEA là nhà bán lẻ và sản xuất nội thất lớn nhất thế giới (Business Insider 2016). IKEA tiêu thụ 1\% tổng sản lượng sản xuất gỗ sản xuất trên thế giới và $60 \%$ sản phẩm IKEA đang sản xuất đến từ gỗ (IKEA 2013). Tổng doanh thu của IKEA năm 2018 tăng 4.7\% so với năm 2017 và đạt 37.1 triệu EURO vào năm 2018 với 1.5 triệu EURO lợi nhuận ròng (INGKA 2018). 
IKEA đang hướng đến việc sử dụng 100\% gỗ từ nguồn bền vững như gỗ tái chế hoặc gỗ có chứng chỉ FSC (Forest Stewardship Council) như một phương pháp trong việc thực hiện mục tiêu giảm toàn bộ phát thải của chuỗi giá trị công ty vào năm 2030.

\section{Hộp 4. Yêu cầu và quy trình mua, nhập gỗ từ các bên cung cấp trong đó có Việt Nam của IKEA \\ IKEA yêu cầu các nhà cung ứng đảm bảo sản phẩm họ bán ra: \\ - Không được có nguồn gốc từ việc khai thác trái phép rừng \\ - Không được có nguồn gốc từ các xung đột xã hội liên quan đến rừng \\ - Không được bắt nguồn từ rừng tự nhiên nguyên sinh và các khu rừng có giá trị bảo tồn cao \\ - Không bắt nguồn từ rừng tự nhiên ở vùng nhiệt đới và cận nhiệt đới đã được chuyển đổi sang rừng trồng hoặc mục đích sử dụng phi lâm nghiệp khác \\ - Không được bắt nguồn từ các loại cây biến đổi gen thương mại được công nhận chính thức và xác định theo địa lý}

(Nguyễn và các cộng sự 2018)

Cùng với cam kết của mình, IKEA hiện thực hoá bằng việc 77\% lượng gỗ họ sử dụng năm 2017 đều từ nguồn gỗ bền vững và đã tăng lên $85 \%$ vào năm 2018. Bên cạnh đó, họ đang yêu cầu các nhà cung cấp có được các chứng chỉ gỗ bền vững để tiếp tục hợp tác như một yêu cầu bắt buộc đối với các nhà cung cấp (IKEA 2018) (Hộp 4). Đây là một trở ngại với các doanh nghiệp cung ứng của Việt Nam khi họ chưa thể đáp ứng được các tiêu chuẩn của nhà sản xuất.

Theo Zhang và Hed 2009, tới thời điểm tháng 3 năm 2009, IKEA có 42 nhà cung cấp tại Việt Nam, và phần lớn trong số đó đạt được cấp độ 2 của tiêu chuẩn IWAY của IKEA đề ra (trong đó có nhiều chỉ tiêu về môi trường như cam kết nguồn gỗ bền vững). Tuy nhiên, theo Forest Trend (Nguyễn và các cộng sự 2018), đến năm 2016 IKEA chỉ còn 10 nhà cung cấp. Điều này cho thấy có thể các nhà cung cấp tại Việt Nam đã không thể bắt kịp với sự chuyển dịch và luật chơi của thị trường quốc tế khi IKEA áp dụng những tiêu chuẩn rất khắt khe và các quá trình nghiêm ngặt trong việc chọn nhà cung cấp, đặt ra yêu câu về khả năng sản xuất quy mô lớn.

Tuy nhiên, vào năm 2016, dù số lượng nhà cung cấp đã giảm xuống đáng kể, tổng giá trị giao dịch giữa IKEA và các nhà cung cấp từ Việt Nam (10 nhà cung cấp) đã đạt đến xấp xỉ 100 triệu EURO (118 triệu USD).

\subsection{Cao su với ví dụ của các công ty sản xuất lốp xe và công nghiệp xe hơi}

Việt Nam là quốc gia sản xuất và xuất khẩu cao su lớn thứ 3 trên thị trường quốc tế (USAID 2018). Việc trồng và mở rộng cao su là nguyên nhân chính dẫn đến phá rừng trên toàn cầu cũng như Việt Nam (USAID 2018).

Cao su với doanh thu 30 tỉ đô la Mỹ là một trong những ngành được người tiêu dùng trên toàn cầu kêu gọi sản xuất bền vững dẫn đến việc nhiều công ty dẫn đầu trong sản xuất lốp xe cam kết sẽ sử dụng nguồn cao su có trách nhiệm từ năm 2016 như Michelin và theo sau là các hãng như Pirelli, Bridgestone, Goodyear, Sumitomo, Continental, Yokohama, Hankook và Toyo Tires. Vào năm 2017, Gerneral Motors là công ty sản xuất ô tô lớn thứ 3 thế giới đã tiên phong trong cam kết sử dụng nguồn cao su có trách nhiệm, tiếp theo sau đó là BMW và Toyota (hai hãng sản xuất xe hơi này trước đó vào năm 2016 đã kí cam kết từ để tập trung tăng lượng cao su bền vững bao gồm cả cao su tự nhiên) (USAID 2018). Năm 2018, Halcyon là công ty xử lý cao su đầu tiên tham gia vào cam kết này không liên quan đến phá rừng và suy thoái rừng (WWF n.d). 
Ngoài ra, máy bay, tàu, xe máy, giày dép, đài đều cần có cao su trong quy trình sản xuất của mình. Phần lớn cao su tự nhiên đang được bán trên thị trường thế giới đến từ Trung Quốc, Ấn Độ, Indonesia và Việt Nam. 4 quốc gia này sản xuất $90 \%$ cao su trên thế giới. Việc chuẩn bị năng lực sẵn sàng cho các công ty sản xuất cao su tại Việt Nam với yêu cầu mới của thị trường là cần thiết và cần phải có nhiều nghiên cứu đánh giá hơn trong lĩnh vực này.

\subsection{Ngành Mĩ phẩm với ví dụ của L'oreal}

Ngành mĩ phẩm cũng là ngành cam kết sản xuất và kinh doanh không phá rừng mạnh mẽ nhất trên thế giới.

Điển hình là các công ty Unilever (n.d), L'oreal đã thông qua chính sách và cam kết Chính sách không phá rừng và khẳng định đến năm 2020, không có sản phẩm thô nào được công ty thu mua, sử dụng có liên quan đến phá rừng. Các sản phẩm của L'oreal sử dụng rất nhiều rất nhiều dầu cọ và dầu đậu nành với các vùng khai thác tập chung chủ yếu ở Indonesia (71\%) và Malaysia (27\%) (L'ORÉAL 2018). Các mục tiêu tham vọng của L'Oreal để đạt đến đích cuối cùng là hoàn toàn không liên quan đến việc phá rừng và làm suy thoái rừng đang được triển khai rất mạnh mẽ, đơn cử như việc đến thời điểm hiện tại, tập đoàn này đã có thể truy được nguồn gốc của $95 \%$ tổng số lượng dầu cọ mà họ sử dụng để có thể kiểm duyệt một cách chặt chẽ.

Ước tính trung bình hàng năm, L'oreal sử dụng 71,000 tấn dầu cọ với những tiêu chuẩn vô cùng khắt khe liên quan đến việc kiểm soát nguồn cung cấp dầu. Từ năm 2010,100\% lượng dầu cọ họ thu mua đạt tiêu chuẩn RSPO thông qua thang đánh giá Segregated (SG), một trong những thang đánh giá khắt khe nhất trên thế giới. Những nhà cung cấp đến từ Indonesia và Malaysia đủ khả năng đáp ứng những tiêu chuẩn này của L'Oreal và nhờ đó mang lại nguồn thu nhập đáng kể cho nền kinh tế của họ. Ở Indonesia, ngành công nghiệp dầu cọ là một trong những mặt hàng xuất khẩu đem lại doanh thu lớn nhất, đóng góp 2.46\% tổng GDP của cả nước (Jakarta Globe 2019).

Đây là một trong những quốc gia đáng học hỏi với mô hình thu hút các tập đoàn quốc tế bằng việc cấp tiến trong khâu cung cấp nguyên liệu đầu vào. Nền kinh tế của Indonesia có được 1 khoản thu lớn nhờ đáp ứng được các điều kiện của chuỗi cung ứng thân thiện và bền vững với môi trường của các tập đoàn đa quốc gia lớn, đơn cử như trường hợp của L'Oreal. 


\section{4 Đề xuất các bước tiếp theo}

Các phân tích trên đây cho thấy các cam kết và thị trường trong tương lai liên quan đến sản xuất và kinh doanh không liên quan đến phá rừng sẽ ảnh hưởng lớn đến nhiều ngành nghề hiện đang đóng vai trò chủ lực trong nền kinh tế của Việt Nam. Chuẩn bị sẵn sàng cho các bên có liên quan hiểu rõ và tiến hành các bước cần thiết hướng tới thị trường năm 2020- 2030 đang trở thành vấn đề cấp thiết. Bảng 2 tóm tắt vai trò của các bên có liên quan cũng như các hoạt động ưu tiên cần thực hiện trong thời gian tới để giúp Việt Nam hội nhập vào thị trường thế giới tốt hơn.

Bảng 2. Vai trò và các hoạt động cần thiết để hỗ trợ Việt Nam tiệm cận với việc sản xuất và kinh doanh không phá rừng.

\begin{tabular}{|c|c|}
\hline $\begin{array}{l}\text { Các bên có } \\
\text { liên quan }\end{array}$ & Nhiệm vụ, trách nhiệm và các bước tiếp theo \\
\hline $\begin{array}{l}\text { Các cơ } \\
\text { quan nhà } \\
\text { nước }\end{array}$ & 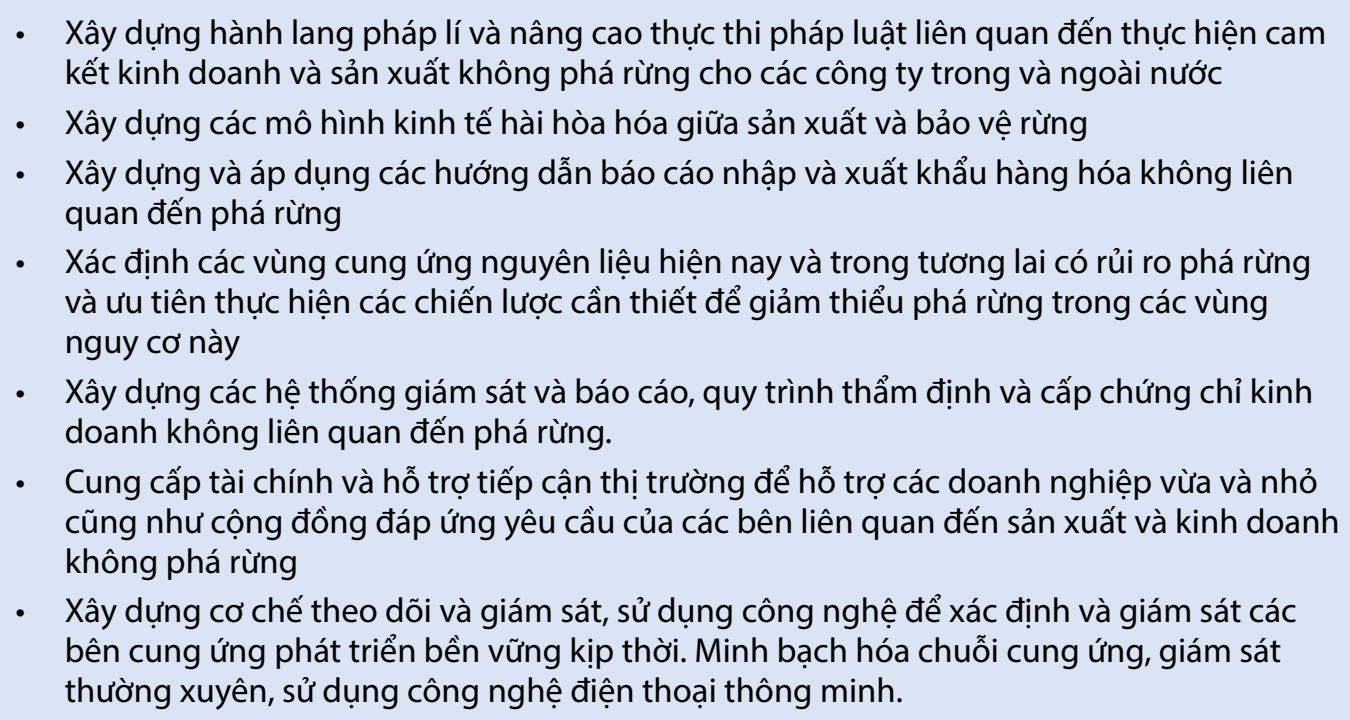 \\
\hline $\begin{array}{l}\text { Các doanh } \\
\text { nghiệp }\end{array}$ & 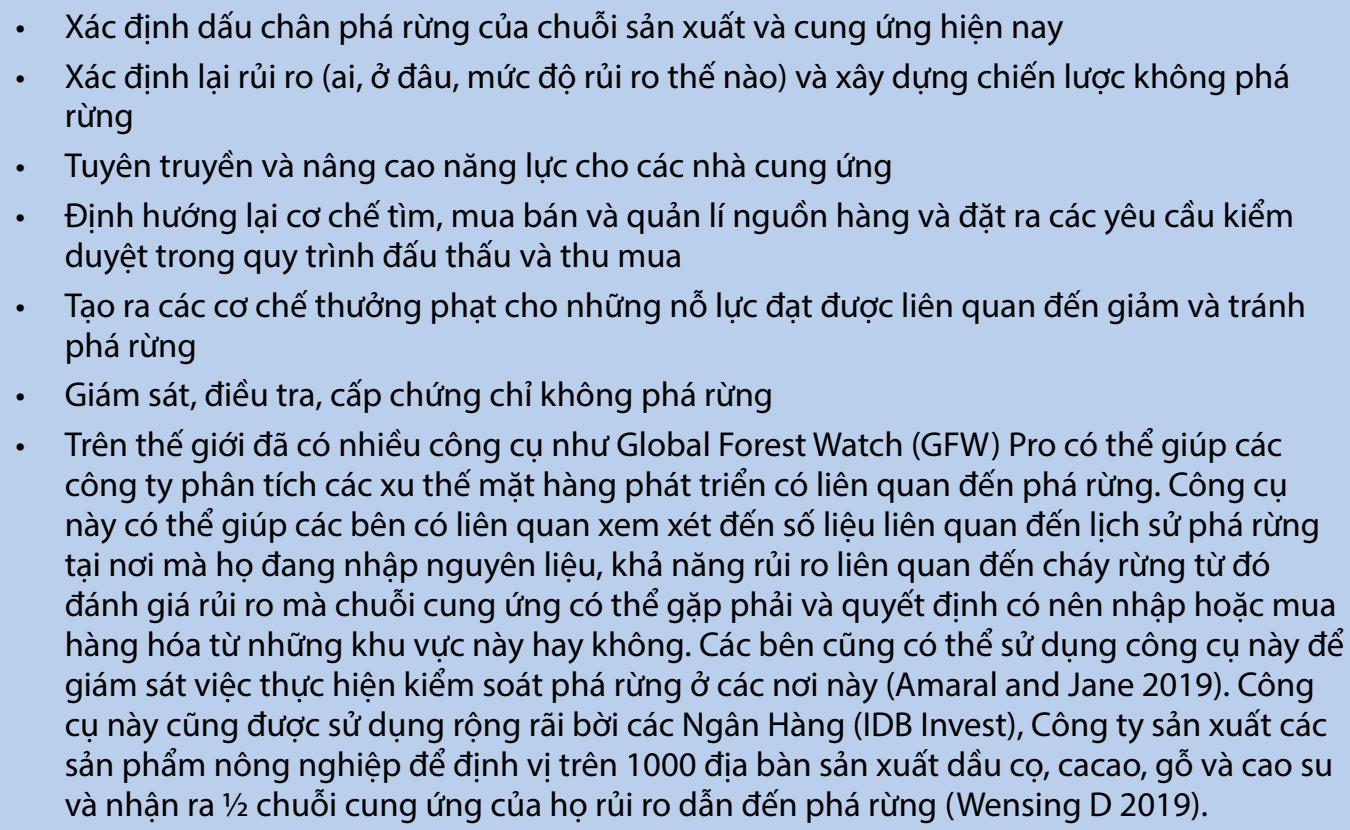 \\
\hline
\end{tabular}


Bảng 2. Tiếp trang trước

\begin{tabular}{|c|c|}
\hline $\begin{array}{l}\text { Các bên có } \\
\text { liên quan }\end{array}$ & Nhiệm vụ, trách nhiệm và các bước tiếp theo \\
\hline $\begin{array}{l}\text { Các doanh } \\
\text { nghiệp }\end{array}$ & 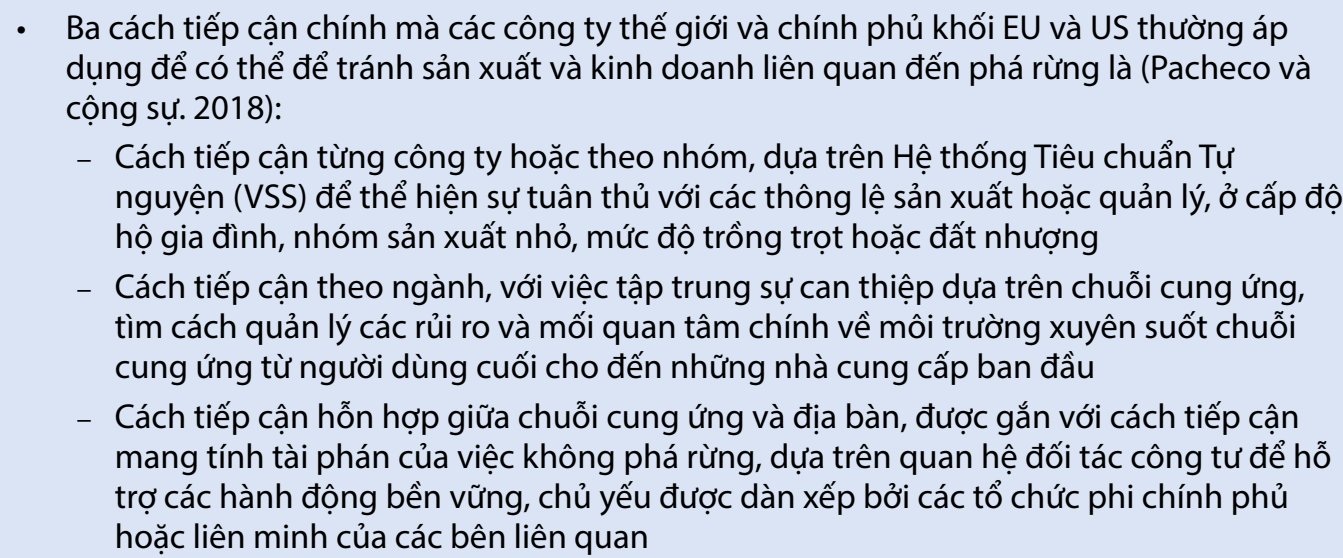 \\
\hline $\begin{array}{l}\text { Các tổ chức } \\
\text { xã hội dân } \\
\text { sự }\end{array}$ & $\begin{array}{l}\text { - Tham gia giám sát độc lập thực thi pháp luật của các bên có liên quan đến cam kết sản } \\
\text { xuất và kinh doanh không phá rừng } \\
\text { - Nâng cao năng lực cho các bên có liên quan để đảm bảo quá trình đánh giá được minh } \\
\text { bạch }\end{array}$ \\
\hline Nghiên cứu & $\begin{array}{l}\text { Mặc dù cam kết kinh doanh không liên quan đến phá rừng có ảnh hưởng mạnh mẽ tới nền } \\
\text { kinh tế của Việt Nam trong nhiều năm tới, chưa có một nghiên cứu đầy đủ nào được tiến } \\
\text { hành để đánh giá mức độ rủi ro của tối thiểu } 22 \text { ngành nghề đã được trình bày báo cáo này. } \\
\text { Báo cáo này phần nào đã tổng hợp số liệu của một số ngành chính nhưng còn cần phân } \\
\text { tích và nghiên cứu cự thể hơn mức độnh hưởng của từng ngành nghề, cũng như xác định } \\
\text { những ưu tiên cẩn hỗ trợ cho doanh nghiệp và nhà nước trong thời gian tới. }\end{array}$ \\
\hline
\end{tabular}




\section{Tài liệu tham khảo}

Amaral L and Jane L. 2019. A New Tool Can Help Root Out Deforestation from Complex Supply Chains. World Resources Institute. Ngày truy cập 27/09/2019. https://www.wri.org/ blog/2019/06/new-tool-can-help-root-out-deforestation-complex-supply-chains

An H. 2016. Nestlé building $\$ 70$ million factory in Hung Yen. Vietnam Economic Times. Ngày truy cập 27/09/2019. https://www.vneconomictimes.com/article/business/nestle-building-70million-factory-in-hung-yen

Aparna B. 2016. Nike's race against climate change. Ngày truy cập 27/09/2019. https://digital.hbs. edu/platform-rctom/submission/nikes-race-against-climate-change/

Business Insider. 2016. How IKEA creator Ingvar Kamprad built the world's largest furniture retailer — and a \$39 billion fortune. Ngày truy cập 27/09/2019. https://www.businessinsider.com/ ingvar-kamprad-10th-richest-2016-1

Caphenguyenchat. Không có ngày xuất bản. Thống kê thị trường xuất khẩu cà phê Việt Nam. [Blog]. Ngày truy cập 27/09/2019. https://caphenguyenchat.vn/thong-ke-thi-truong-xuat-khau-caphe-viet-nam.html

Cổng thông tin quốc gia về đăng kí doanh nghiệp. 2018. Tình hình các doanh nghiệp Việt Nam trong lĩnh vực Cà phê. Ngày truy cập 27/09/2019. https://dangkykinhdoanh.gov.vn/vn/tintuc/611/4875/tinh-hinh-cac-doanh-nghiep-viet-nam-trong-linh-vuc-ca-phe.aspx

[VIRAC] Công ty cổ phần nghiên cứu ngành tư vấn Việt Nam. 2019. Ngành dệt may Việt Nam. Ngày truy cập 27/09/2019. https://viracresearch.com/industry/bao-cao-tieu-chuan-nganh-det-mayviet-nam-q1-2019

CSIMarket. Không có ngày xuất bản. Nike Inc's Suppliers Performance. Ngày truy cập 27/09/2019. https://csimarket.com/stocks/suppliers_glance.php?code=NKE

Diễn Đàn Doanh Nghiệp. 2019. Ngành gỗ năm 2019: Triển vọng lớn và cơ hội bứt phá. Ngày truy cập 27/09/2019. https://enternews.vn/nganh-go-nam-2019-trien-vong-lon-va-co-hoi-butpha-144662.html

Dũng T. 2018. Trên có Vinamilk, dưới có Nestlé, doanh nghiệp ngành sữa đang tồn tại như thế nào?. The Leader. Ngày truy cập 27/09/2019. https://theleader.vn/tren-co-vinamilk-duoi-co-nestledoanh-nghiep-nganh-sua-dang-ton-tai-nhu-the-nao-20180514164933732.htm

Forest Trends. 2016. Delinking Deforestation from Corporate Supply Chains Proves a Tall Task. London: England. Ngày truy cập 27/09/2019. https://www.forest-trends.org/wp-content/ uploads/2016/07/doc_5251.pdf

Gỗ Việt. 2019. Mục tiêu xuất khẩu gỗ 11 tỉ USD năm 2019: Trên đường về đích. Ngày truy cập 27/09/2019. http://goviet.org.vn/bai-viet/muc-tieu-xuat-khau-go-11-ti-usd-nam-2019-trenduong-ve-dich-9033

IKEA. 2013. IKEA Group Sustainability Report FY 2013. Ngày truy cập 27/09/2019. https://www.ikea. com/ms/en_US/pdf/sustainability_report/sustainability_report_2013.pdf

IKEA. 2018. IKEA Sustainability Report FY 2018. Ngày truy cập 27/09/2019. https:// gbl-sc9u2-prd-cdn.azureedge.net/-/media/aboutikea/pdfs/sustainability-report. pdf?la $=e n \& r e v=4 c a 3256 \mathrm{dc} 8 \mathrm{~b} 545$ ee9af13de0d6184678\&hash=612AA642E0E181D58C83C88A 6229D1A0

INGKA. 2018. Annual \& Sustainability Summary Report FY 2018. Ngày truy cập 27/09/2019. https:// annualreport.ingka.com/wp-content/uploads/2019/02/lngka_AR18_190206_2_3.pdf

Jakarta Globe. 2019. Palm Oil Continues to Makes Significant Contribution to Indonesian Economy: Gapki. Ngày truy cập 27/09/2019. https://jakartaglobe.id/context/palm-oil-continues-tomakes-significant-contribution-to-indonesian-economy-gapki/

Joshua W. Không có ngày xuất bản. 2018. The battle for sporting goods supremacy: Nike vs Adidas. Ngày truy cập 27/09/2019. https://www.ig.com/en-ch/news-and-trade-ideas/shares-news/thebattle-for-sporting-goods-supremacy--nike-vs-adidas-180329 
L'ORÉAL. 2018. L'ORÉAL TAKES PALM OIL SUSTAINABLE SOURCING ONE STEP BEYOND. Ngày truy cập 27/09/2019. https://www.loreal.com/sharing-beauty-with-all-innovating/achieving-zerodeforestation/I\%E2\%80\%99or\%C3\%A9al-takes-palm-oil-sustainable-sourcing-one-stepbeyond

Lan N. 2019. Nestlé Vietnam expands Nestlé Bong Sen Factory. Vietnam Economic Times. Ngày truy cập 27/09/2019. https://www.vneconomictimes.com/article/business/nestle-vietnamexpands-nestle-bong-sen-factory

Lê KL. 2018. Năm 2018 - Xuất khẩu dệt may đạt trên 36 tỷ USD. Ngày truy cập 27/09/2019. https:// baomoi.com/nam-2018-xuat-khau-det-may-dat-tren-36-ty-usd/c/28989244.epi

Mat Mc. 2009. Nike Says No To Deforestation Leather - Not That They Ever Used It. Ngày truy cập 27/09/2019. https://www.treehugger.com/corporate-responsibility/nike-says-no-todeforestation-leather-not-that-they-ever-used-it.html

Mongabay. 2009. Nike, Unilever, Burger King, IKEA may unwittingly contribute to Amazon destruction, says Greenpeace. Ngày truy cập 27/09/2019. https://news.mongabay. com/2009/06/nike-unilever-burger-king-ikea-may-unwittingly-contribute-to-amazondestruction-says-greenpeace/

Nestlé. Không có ngày xuất bản. By Emily Kunen Nestlé Global Responsible Sourcing Leader, Palm Oil \& Seafood. Ngày truy cập 27/09/2019. https://www.nestle.com/stories/responsiblesourcing-no-deforestation

Nguyen VQ, To XP, Nguyen TQ, Cao TC. 2018. Linking Smallholder Plantations to Global Markets. Forest Trends. Ngày truy cập 27/09/2019. https://www.forest-trends.org/publications/linkingsmallholder-plantations-to-global-markets/

Nike News. 2009. NIKE, Inc. commits to helping halt Amazon deforestation. Washington: US. Ngày truy cập 27/09/2019.https://news.nike.com/news/nike-inc-commits-to-helping-halt-amazondeforestation

Nike. Không có ngày xuất bản. Nike manufacturing map. Ngày truy cập 27/09/2019. http:// manufacturingmap.nikeinc.com/

Pacheco P, Bakhtary H, Camargo M, Donofrio S, Drigo I and Mithöfer D. 2018. The private sector: Can zero deforestation commitments save tropical forests? In Angelsen A, Martius C, De Sy V, Duchelle AE, Larson AM and Pham TT, eds. Transforming REDD+: Lessons and new directions. p. 161-173. Bogor, Indonesia: CIFOR.

Siegle L. 2013. Luxury leather and the Amazon. Ngày truy cập 27/09/2019. https://www. theguardian.com/environment/2013/mar/03/luxury-leather-and-amazon-deforestation

South Pole. Không có ngày xuất bản. Deforestation Free Supply Chain. Ngày truy cập 27/09/2019. https://www.southpole.com/sustainability-solutions/deforestation-free-supply-chains

The Forbes. Không có ngày xuất bản. The Forbes Fab 40: The World's Most Valuable Sports Brands. Ngày truy cập 27/09/2019. https://www.forbes.com/pictures/mlm45jemm/the-most-valuablecompany-brands/\#ff37f49a7ece

The sustainable trade initiative. 2019. Dutch trade mission signs agreement to reduce water use and protect forests in Vietnamese coffee production areas. Ngày truy cập 27/09/2019. https:// www.idhsustainabletrade.com/news/dutch-trade-mission-signs-agreement-to-reduce-wateruse-and-protect-forests-in-vietnamese-coffee-production-areas/

The sustainable trade initiative. 2019. Europe "dangerously behind" on achieving deforestation-free soy, palm, timber, cocoa. Ngày truy cập 27/09/2019. https://www.idhsustainabletrade.com/ news/europe-dangerously-behind-on-achieving-deforestation-free-soy-palm-timber-cocoa/

To XP and Canby K. 2011. BASELINE STUDY 3, Vietnam: Overview of Forest Law Enforcement, Governance and Trade. Forest Trend. Ngày truy cập 27/09/2019. https://data. opendevelopmentmekong.net/dataset/baseline-study-3-vietnam-overview-of-forestgovernance-and-trade/resource/bc59efd3-3f89-4b6f-ad22-3b71b6dbffa1?type=library_record

Unilever. Không có ngày xuất bản. UNILEVER'S POSITION ON ELIMINATING DEFORESTATION. Ngày truy cập 27/09/2019. https://www.unilever.com/Images/eliminating-deforestation-positionstatement_tcm244-423148_en.pdf

[USAID] United States Agency for International Development. 2018. RUBBER HITS THE ROAD: PRIVATE SECTOR DIALOGUE ON SUSTAINABLE RUBBER IN VIETNAM. USAID Green Invest Asia. 
Ngày truy cập 27/09/2019. https://greeninvestasia.com/rubber-hits-the-road-private-sectordialogue-on-sustainable-rubber-in-vietnam/

VietnamPlus. 2019. Nestle inaugurates new coffee capsule production line in Vietnam. Ngày truy cập 27/09/2019. https://en.vietnamplus.vn/nestle-inaugurates-new-coffee-capsuleproduction-line-in-vietnam/134923.vnp

Walker NF, Patel SA, \& Kalif KA. 2013. From Amazon pasture to the high street: deforestation and the Brazilian cattle product supply chain. Tropical Conservation Science, 6(3), 446-467. https:// journals.sagepub.com/doi/full/10.1177/194008291300600309

Wensing D. 2019. Reality check: How to make zero-deforestation pledges work for forests, economy and social inclusion. The sustainable trade initiative. Ngày truy cập 27/09/2019. https://www. idhsustainabletrade.com/news/reality-check-how-to-make-zero-deforestation-pledges-workfor-forests-agriculture-and-social-inclusion/

[WWF] World Wildlife Fund. Không có ngày xuất bản. Transforming the global rubber market. Ngày truy cập 27/09/2019. https://www.worldwildlife.org/projects/transforming-the-global-rubbermarket

Zhang Y and Hed CJ. 2009. Exploring the Benefits of Implementing CSR Practices: from a Supplier Perspective -A case study of IKEA and its Vietnamese Suppliers. [Master Degree Project]. Gothenburg: University of Gothenburg. 

Các báo cáo chuyên đề của CIFOR bao gồm các kết quả nghiên cứu sơ bộ hoặc nâng cao về các vấn đề về rừng ở các khu vực nhiệt đới và cần được công bố vào thời điểm thích hợp để tạo ra và thúc đẩy các cuộc thảo luận. Nội dung báo cáo đã được rà soát nội bộ nhưng chưa trải qua quá trình bình duyệt từ các chuyên gia bền ngoài tổ chức.

Sản xuất và kinh doanh không liên quan đến phá rừng là yêu cầu của thị trường toàn cầu từ nay tới năm 2030. Hơn 1000 thể chế tài chính (ví dụ: ngân hàng, quỹ ủy thác, nhà tài trợ), và 600 tập đoàn đa quốc gia trên toàn cầu đã cam kết sản xuất và cung cấp các sản phẩm nông sản không liên quan đến phá rừng và đang xây dựng quy trình kiểm tra, sàng lọc, cấp chứng chỉ cho các bên cung ứng dịch vụ và các nước sản xuất sản phẩm nông lâm sản. Chính phủ của các nước khối Châu Âu, Châu Mỹ và Châu Úc cũng đang ráo riết xây dựng hành lang pháp lí để kiểm duyệt và cấp chứng chỉ cho các sản phẩm nhập khẩu vào nước họ.

Tại Việt Nam, có 92 công ty trong và ngoài nước kinh doanh trên 21 lĩnh vực và ngành nghề đã kí cam kết vào lộ trình không phá rừng cho tới năm 2020. 21 lĩnh vực bao gồm: thời trang - Trang phục \& giày dép, Nông nghiệp, Xây dựng Mỹ phẩm \& chăm sóc cá nhân, Chuỗi bán lẻ thực phẩm, Lâm nghiệp; Nhà cửa - Nội thất \& sàn nhà - Vật dụng sửa chữa nhà cửa; Hàng tiêu dùng Thực phẩm, Giấy và bao bì, in ấn và xuất bản, Công nghiệp ô tô - Cao su - Sản xuất ô tô. Các công ty này đóng góp lớn trong GDP quốc gia và phát triển kinh tế địa phương, đồng thời là người mua chủ lực cho các mặt hàng nông sản bao gồm cà phê, gỗ, đỗ tương, thịt gia súc gia cầm.

Tuy nhiên, các doanh nghiệp và chuỗi cung ứng sản phẩm nông lâm sản tại Việt Nam chưa hề được chuẩn bị cả về kiến thức, kĩ năng và quy trình để đáp ứng với các đòi hỏi mới này của thị trường. Nếu hiện trạng này không được nghiên cứu và có phương hướng chuẩn bị lâu dài, ngành nông lâm sản của Việt Nam có nguy cơ không còn cạnh tranh trong thị trường mới, dẫn đến thiệt hại kinh tế to lớn cho nền kinh tế nước nhà.

Chính phủ cần xây dựng hành lang pháp lí để hỗ trợ và giám sát các công ty thực hiện cam kết này, đồng thời nâng cao năng lực cho các bên có liên quan để đón đầu và đáp ứng với yêu cầu của thị trường mới, đảm bảo vị thế vững chắc của các ngành nông lâm sản và đóng góp bền vững của các ngành này vào nền kinh tế quốc dân trong 30 năm sắp tới.

\begin{tabular}{|l|l|l|l|l|l} 
Chương trình nghiên cứu của CGIAR về Rừng, Cây gỗ và Nông lâm kết hợp (FTA) là chương trình \\
phát triển nghiên cứu lớn nhất thế giới nhằm nâng cao vai trò của rừng, cây gỗ và nông lâm kêtt hợp \\
với mục tiêu phát triển bền vững và đảm bảo lương thực để ứng phó với biến đổi khí hậu. CIFOR \\
chủ trì các nghiên cứu FTA trong mối quan hệ đối tác chiến lược với Bioversity International, CATIE, \\
CIRAD, INBAR, ICRAF và TBI. \\
Nghiên cứu này được hỗ trợ bởi Quỹ đối tác CGIAR: cigar.org/funders/ \\
$\begin{array}{l}\text { PROGRAM on } \\
\text { Forests, Trees and }\end{array}$
\end{tabular}

cifor.org | forestsnews.cifor.org tiến hành các nghiên cứu sáng tạo, nâng cao năng lực của các bên đối tác, tích cực tham gia đối thoại với các bên liên quan để hỗ trợ định hình chính sách và thực tiễn tác động tới rừng và con người. CIFOR là tổ chức nghiên cứu thuộc liên minh CGIAR và chủ trì các chương trình nghiên cứu của CGIAR về Rừng, Cây gỗ và Nông lâm kết hợp (FTA). Trụ sở chính của CIFOR đặt tại Bogor, Indonesia và các văn phòng của CIFOR có mặt tại Nairobi, Kenya; Yaounde, Cameroon; Lima, Peru và Bonn, Germany. 